\title{
A laryngealis electromyographia szerepe a hangszalag-mozgászavarok diagnosztikájában és az alkalmazott kezelés kiválasztásában
}

\author{
Bach Ádám dr. ${ }^{1}$ - Sztanó Balázs dr. ${ }^{1}$ - Kiss József Géza dr. ${ }^{1}$ \\ Gerd Fabian Volk dr. ${ }^{2}$ - Andreas Müller dr. ${ }^{3}$ - Claus Pototschnig dr. ${ }^{4}$ \\ Rovó László dr. ${ }^{1}$ \\ 'Szegedi Tudományegyetem, Általános Orvostudományi Kar, \\ Fül-Orr-Gégészeti és Fej-Nyaksebészeti Klinika, Szeged \\ ${ }^{2}$ Jena University Hospital, Department of Otorhinolaryngology, Jena, Germany \\ ${ }^{3}$ SHR Wald-Klinikum Gera, Department of Otorhinolaryngology, Gera, Germany \\ ${ }^{4}$ University of Innsbruck, Department of Otorhinolaryngology, Innsbruck, Austria
}

\begin{abstract}
A hangszalag-immobilitást okozó kórképek terápiás lehetőségeinek fejlődése megkövetelte a diagnosztikai módszerek párhuzamos megújulását is. Az utóbbi években ez a tendencia vezetett a már 70 éve ismert laryngealis electromyographia újrafelfedezéséhez. A nemzetközi irodalom áttekintésével és saját tapasztalataik alapján a szerzők bemutatják az eljárás alkalmazásának indikációját, technikai követelményeit és módszertanát, különös tekintettel az eredmények értékelésére. A laryngealis electromyographia lehetővé teszi a beidegzési zavarból és a mechanikus fixációból adódó hangszalag-immobilitás elkülönítését. Hangszalagbénulás esetén továbbá segítséget nyújt az idegsérülés fokának objektív megbecsülésében, a betegség prognózisának felállításában, az esetleges hangréstágító beavatkozás indikációjában és pontos típusának meghatározásában. A dinamikus rehabilitációs beavatkozások várható egyre szélesebb elterjedése sem képzelhetô el az eljárás rutinszerú alkalmazása nélkül. Ezek a lehetőségek mindenképpen szükségessé teszik a laryngealis electromyographia bevezetését a gégészeti centrumokban.

Orv Hetil. 2018; 159(8): 303-311.
\end{abstract}

Kulcsszavak: laryngealis electromyographia, hangszalagbénulás, hangszalag-mozgászavar

The role of laryngeal electromyography in the diagnosis of vocal cord movement disorders

\begin{abstract}
The development of the therapeutic possibilities of vocal cord immobility necessitated the parallel renewal of diagnostic methods. In the last years, laryngeal electromyography, which was first introduced more than 70 years ago, has been re-discovered. After reviewing the international literature and their own experience, the authors present the indications, technical requirements, method and, particularly, the evaluation of the results of this procedure. Laryngeal electromyography makes the differentiation between mechanical fixation and immobility with neurological origin of the vocal folds possible. In case of laryngeal paralysis/paresis it also evaluates objectively the severity of neural injury, the prognosis of the disease and the necessity of any glottis-widening procedure. The widespread application of dynamic rehabilitation interventions is not conceivable without the routine application of laryngeal electromyography, so this sensitive diagnostic tool has to be introduced in all laryngological centers.
\end{abstract}

Keywords: laryngeal electromyography, vocal cord palsy, vocal cord immobility

Bach Á, Sztanó B, Kiss JG, Volk GF, Müller A, Pototschnig C, Rovó L. [The role of laryngeal electromyography in the diagnosis of vocal cord movement disorders]. Orv Hetil. 2018; 159(8): 303-311.

(Beérkezett: 2017. október 26; elfogadva: 2017. december 15.) 


\section{Rövidítések}

ELS = European Laryngological Society $; \mathrm{EMG}=$ electromyographia; HIV = (human immundeficiency virus) emberi immunhiány-előidéző vírus; LEMG = laryngealis electromyographia; $\mathrm{m} . \mathrm{CAP}=$ musculus cricoarytenoideus posterior; $\mathrm{m}$.TA $=$ musculus thyroarytenoideus; $\mathrm{SPA}=$ spontán patológiás aktivitás

A hangszalagok mozgászavarainak diagnosztikája mind a hazai, mind a nemzetközi viszonylatban dominálóan az endoscopos kép és az ezt kiegészítő stroboscopia alapján történik. Kellő tapasztalat birtokában ezek a szubjektív módszerek teszik lehetővé a mechanikai fixáltságból és az idegsérülésből adódó mozgászavarok differenciáldiagnosztikáját és a gégeizmok rendellenes múködésének vizsgálatát (pl. spasmodicus dysphonia vagy myasthenia gravis esetén), azonban a gégeizmok paresise vagy paralysise esetén nem adnak lehetőséget a beidegzési zavarok súlyosságának megállapítására és a betegség prognózisának felállítására sem [1]. Hangszalagbénulás esetén ezek a tényezők alapjaiban határozzák meg az esetleges korrekciós mútét indikációját és típusát. A terápiás módszerek fejlődése miatt az utóbbi évtizedekben egyre fontosabbá vált egy olyan objektív diagnosztikai módszer rutinszerü bevezetése, amely választ adhat a fenti problémákra. Kézenfekvő megoldást nyújt a neuromuscularis betegségek diagnosztikájában évtizedek óta alkalmazott electromyographia gégeizmokon történő alkalmazása. Habár a laryngealis electromyographia (LEMG) több mint 70 éve ismert, a legtöbb fül-orr-gégész, illetve foniáter a mai napig nem alkalmazza a mindennapi gyakorlatban. Ez nagy valószínúséggel arra vezethetô vissza, hogy az utóbbi évekig nem létezett egységes álláspont a vizsgálat elvégzésének módszeréről, az eredmények értékeléséról és a vizsgálat klinikai gyakorlatban betöltött szerepéről [2-5]. Annak érdekében, hogy az említett kérdésekben konszenzus jöjjön létre, a European Laryngological Society (ELS) neurolaryngologiai munkacsoportja célul tüzte ki, hogy meghatározzák a LEMG alkalmazásának irányvonalait. Klinikánk évek óta részt vesz a nemzetközi munkacsoport munkájában, a 2012-ben publikált európai javaslatok módosításában, értékelésében $[6,7]$. A diagnosztikus eljárás módszertani alapjainak minél szélesebb körben történő megismertetése és az optimális terápia meghatározásában betöltött szerepének bemutatása kiemelt fontosságú, hiszen az utóbbi alapvetően határozza meg a betegcsoport életminőségét is.

\section{Módszer}

\section{Indikáció/kontraindikáció}

A gégeizmok beidegzési zavara, a cricoarytenoidealis ízület diszlokációja vagy ankylosisa, a glottis hegesedése vagy tumoros fixációja klinikailag hasonló tünetegyüttes- hez vezet [8]. A LEMG elsődleges célja a hangszalag idegsérüléséből és mechanikus fixáltságából adódó immobilitásának elkülönítése. Idegsérülés esetén a myographia továbbá segítséget nyújt a sérülés fokának megállapításában és a reinnerváció prognózisának felállításában is. A LEMG hasznos eszköz továbbá spasmodicus dysphonia vagy a hangszalag(ok) medializálásának igénye esetén is, amelynek során célunk a hangszalagba injektált anyag (pl. botulinumtoxin, hialuronsav) minél pontosabb célba juttatása [9-12].

Vázizmok vizsgálata esetén az electromyographiának abszolút kontraindikációja gyakorlatilag nincs [13]. A gége speciális helyzetéból adódóan laryngealis electromyographia végzésekor azonban különös figyelemmel kell eljárnunk, mivel instabil légút esetén LEMG-t nem végezhetünk. A rendkívül ritka, de potenciálisan fatális komplikációk miatt (főként kétoldali hangszalag-immobilitás esetén) az esetleges intubációra készen kell állni, conicotomiás szettnek elérhetônek kell lennie. Véralvadási zavar, a célterület sebe, ödémája, ingerléses vizsgálatkor pedig a pacemaker relatív kontraindikációt jelent. A vérrel átvihető betegségek (HIV, hepatitis) a megfelelő sterilitással megelőzhetők. LEMG-t az eddigiekben kizárólag felnőtt betegeken végeztünk, de általános érzéstelenítésben speciális relaxáció nélküli anesztézia alkalmazásával lehetőség van gyermeken történő vizsgálatra is [14].

\section{Technikai követelmények}

Elektróda: Electromyographia során az izomrostok innervációjakor létrejövő potenciálok szummálódott végeredményét regisztráljuk extracellularisan elhelyezkedő elektróda segítségével. Ezt a szummációs potenciált mozgatóegység-potenciálnak nevezzük. Regisztrálásához felszíni vagy transcutan elektródák használhatók. A diagnosztikus célból leggyakrabban végzett transcutan LEMG-hoz koncentrikus túelektróda használata javasolt: $50 \mathrm{~mm}$ hosszúságú tû lehetôvé teszi a gége hátsó felszínén elhelyezkedő musculus cricoarytenoideus posterior (m.CAP) elérését is a gyürüporcon keresztül. Ehhez azonban kellően merev, legalább $0,45 \mathrm{~mm}$ átmérőjü elektróda szükséges. A mérések megismételhetősége és összehasonlíthatósága érdekében érdemes mindig azonos típusú elektródát használni (TECA Elite, Disposable Concentric Needle Electrodes, $37 \mathrm{~mm} \times 26$ G; $50 \mathrm{~mm} \times$ 26 G; Natus Neurology Inc., Middleton, WI, USA).

Mikrofon: A beteg nyakára erősített mikrofonnal történő hangfelvétel a myographiás eszköz egyik csatornáján rögzíthető, ami jelentősen megkönnyíti a gégeizmok fonációval kapcsolatos myoelectronicus aktivitásának és a különböző gégeizmok agonista és antagonista múködésének összehasonlítását. Emellett a hangfelvétel lehetőséget biztosít a vizsgáló valós idejü verbális megjegyzéseinek szimultán rögzítésére is.

Termisztor, mellkasi mozgásokat mérööp: A be- és kilélegzett levegő hőmérséklete a beteg orra vagy tracheoto- 


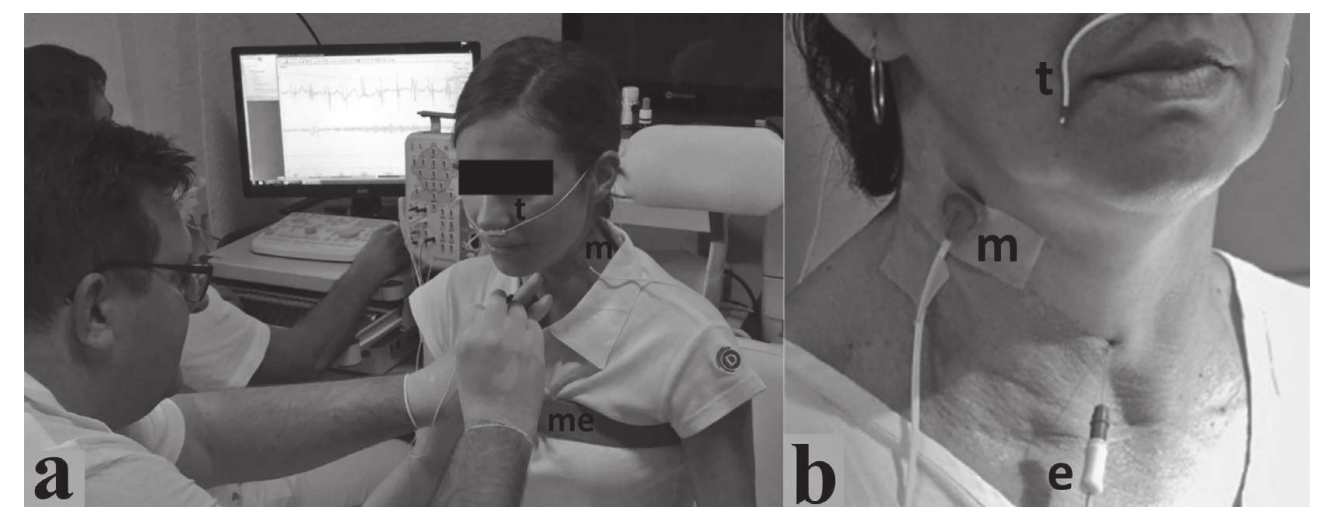

1. ábra

$\mid \begin{aligned} & \text { A laryngealis electromyographia kivitelezése a musculus cricoarytenoideus posterior (a) és a musculus thyroarytenoideus (b) vizsgálatakor } \\ & \text { e = elektróda; } m=\text { mikrofon, } m e=\text { mellkasi öv; } t \text { = termisztor }\end{aligned}$

miás nyílása elé helyezett termisztorral mérhető. Ezzel párhuzamosan egy piezoelektromos elven múködő mellkasi öv is monitorozza a légzési mozgásokat. A két szenzor lehetővé teszi a vizsgált gégeizmok aktivitásának és a légzési fázisok időbeli összefüggésének pontos rögzítését.

Indirekt laryngoscopia: A gégemozgások transnasalis fiberendoscopos követése további adatokat biztosít az elvezetett izomválaszok és az általuk biztosított valós hangszalagmozgások közötti kapcsolat értékeléséhez.

Vizsgálatainkhoz egy 12 csatornás, a gégeizmok elektromos stimulálására is alkalmas NIHON KOHDEN: Neuropack Xl (Nihon Kohden Corp., Tokyo, Japan) electromyographot használunk. Az adatokat egy speciálisan erre a célra írt, MATLAB-ban (The MathWorks Inc., Natick, MA, USA) futtatható LEMG analizáló kód és az Audacity 2.1.3 software (http://audacityteam. org/) segítségével dolgozzuk fel és értékeljük [15].

\section{A vizsgálat menete}

A laryngealis electromyographia olyan invazív diagnosztikai eljárás, amely a beteg aktív együttmúködését követeli meg. A vizsgálat jellegéből adódóan nem mellőzhetô a megfelelő tájékoztatás és a beteg írásos beleegyezése. A myographiát a fej-nyaki régió alapos vizsgálata kell, hogy megelőzze, beleértve ebbe az indirekt laryngoscopiát és a videostroboscopiát is. Ilyen módon feltárhatók az esetleges anatómiai deformitások, korábbi mútétek okozta elváltozások, infekciók - összességében minden olyan állapot, amely megnehezítheti az elektródák bevezetését. A LEMG előtt érdemes rögzíteni a beteg hangját és légzésfunkciós paramétereit is. A vizsgálatot innervációs zavar gyanúja esetén a hangszalag-immobilitás kialakulása után leghamarabb 2 héttel javasolt elvégezni [4].

A vizsgálat alatt a beteg kényelmes ülő pozíciót vesz fel ( $1 / a$ és $1 / b$ ábra). Amennyiben párhuzamosan fiberoscopiát nem végzünk, a gége nyálkahártyájának és a nyak bőrének érzéstelenítése nem feltétlenül indokolt. A szükséges szenzorok, a földelés felhelyezése és a bőr fertőtlenítése után kezdjük meg a méréseket. Javasolt a vizsgálatot a musculus thyroarytenoideus (m.TA) mérésével kezdeni. Az elektróda megfelelő pozicionálásához alapvető fontosságú a ligamentum cricothyroideum (ligamentum conicum) kitapintása. A tüt a nyak középvonalában közvetlenül a pajzsporc alsó éle alatt vezetjük be. A középvonaltól kb. $30^{\circ}$-ra lateralisan a tút cranialis irányba billentve a ligamentum conicumon történő áthaladás után (a nyaki lágyrészektől és a belépési szögtől függően) $\mathrm{kb} .15 \mathrm{~mm}$-re várható a musculus thyroarytenoideus elérése $(1 / b, 2 / a$ és $2 / b$ ábra $)$. Lényeges, hogy az elektróda submucosusan érje el a hangszalag izomzatát. Hirtelen jelentkező köhögési inger és a fonációkor regisztrált myographiás sinushullámok jelzik, hogy a tưelektróda vége a légútban van. A tû pozíciójának ellenőrzése a következőképpen zajlik: a hangszalag intakt beidegzése esetén, amennyiben az elektróda a m.TA-ban van, fonációkor (a beteg "í" hangot ad) az elektromos aktivitás fokozódik. Nyeléskor szintén rövid időre fokozódik az aktivitás. Mély belégzéskor a nyugalmi aktivitás csökkenése látható.

A musculus cricoarytenoideus posterior (m.CAP) vizsgálata a gyưrüporc pecsétjének penetrálásával valósítható meg. A túelektróda beszúrásakor itt is a legfontosabb anatómiai támpont a ligamentum conicum. Az elektróda a bőrön és a ligamentum conicumon történő áthaladása után a légútba jut. Ekkor az elektródavég szabad vibrálása miatt sinushullámokat regisztrálunk, illetve a nyálkahártya irritációja miatt köhögést tapasztalunk. A középvonaltól 5-10 mm-re lateralisan a tû lassú forgatásával és posterior irányba történő tolásával átfúrjuk a gyưrüporc lamináját, és elérjük a musculus cricoarytenoideus posteriort $(1 / a, 2 / c$ és $2 / d$ ábra). Amennyiben az elektródát túl mélyen vezetjük be, az a cricopharyngealis izomzatba fog jutni. Ekkor folyamatosan erős aktivitást észlelünk, amely nyeléskor hirtelen csökken. A tú pozíciójának ellenőrzése a következőképpen zajlik: a hangszalag intakt beidegzése esetén, amennyiben a tû a m.CAPban van, szippantáskor az elektromos aktivitás fokozódik, nyeléskor és fonációkor az aktivitás csökken. 


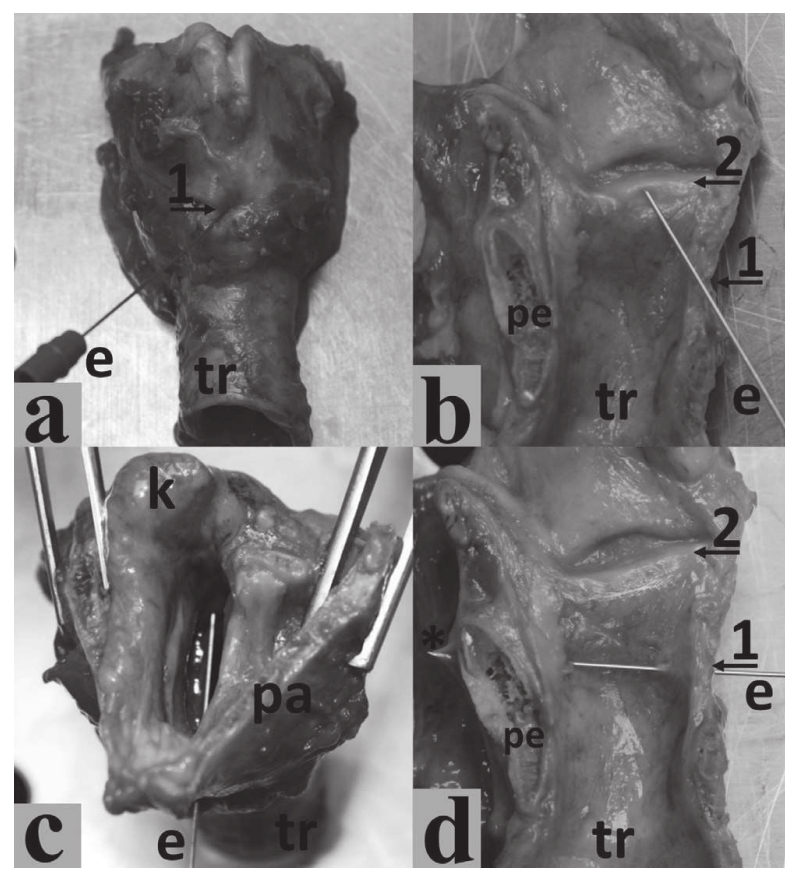

2. ábra \begin{tabular}{|l} 
A túelektróda helyzete a bal oldali musculus thyroarytenoideus \\
$(\mathrm{a}, \mathrm{b})$ és a musculus cricoarytenoideus posterior $(\mathrm{c}, \mathrm{d})$ vizsgála- \\
takor. a: A túelektróda a ligamentum conicumon keresztül hatol \\
a gégébe (cadaver gége, elölnézet). b: A túelektróda hegye a bal \\
oldali hangszalag izomzatában látható. A túelektróda a szemlél- \\
tetés érdekében a vizsgálati protokollal ellentétben nem a nyál- \\
kahártya alatt helyezkedik el (cadaver gége, bal oldali gégefél). \\
c: A túelektróda a ligamentum conicumon és a gége lumenén \\
áthaladva éri el a gyúrúporc pecsétjét (cadaver gége, felülnézet). \\
d: A túelektróda a gyúrúporc pecsétjének átfúrása után éri el a \\
musculus cricoarytenoideus posteriort. A szemléltetés érdeké- \\
ben a túelektróda hegye $\left({ }^{*}\right)$ az optimálisnál nagyobb mértékben \\
penetrálja a gyúrúpor pecsétjét (cadaver gége, bal oldali gégefél) \\
$\mathrm{l}=$ ligamentum conicum; $2=$ bal oldali hangszalag; $\mathrm{e}=$ túelekt- \\
róda; $\mathrm{k}=$ bal oldali kannaporc; $\mathrm{m}=$ mikrofon; pa = pajzsporc; \\
pe $=\mathrm{a}$ gyúrúporc pecsétje; $\mathrm{t}=$ termisztor; $\mathrm{tr}=$ trachea
\end{tabular}

A gégeizmok agonista és antagonista aktiválódásának vizsgálata érdekében az adatokat fonáció (a beteg háromszor hosszan 'î' hangot ad), erőltetett belégzés (orron/tracheotomiás nyíláson keresztül történő gyors szippantás), nyugodt be- és kilégzés (30 s-ig történő nyugodt be- és kilégzés fonáció nélkül) alatt is vizsgáljuk. A differenciáldiagnosztikát a m.CAP elektromos stimulálásával lehet kiegészíteni. Ezt a beavatkozást jelenleg csak kutatási célból, általános érzéstelenítésben végezzük.

\section{A laryngealis electromyographia értékelése}

A gégeizmok neurofiziológiai különlegességei és a technikai nehézségek miatt még jól képzett szakembernek is problémát okozhat a LEMG eredményeinek interpretálása. Éppen ezért szükséges, hogy a vizsgálat elvégzése és értékelése előre megtervezetten, standardizálva történjen. Electromyographia során a vázizmok elektromos aktivitását nyugalomban és különböző erősségű akaratla- gos aktivitás esetén kell elemezni. Laryngealis electromyographia során ez igen nehéz, mivel az egyes gégeizmok akaratlagos aktivitásának mértékét nehéz szabályozni, illetve a gége izmai komplex mozgási mintázatokat követnek, és ezek a mozgások mindig több izomcsoportot involválnak [6]. Hangszalag-immobilitás esetén a különböző vizsgálómódszerek önmagukban nem bizonyító erejűek, minden beteg esetén indokolt a komplex kivizsgálás.

EMG során a mozgatóegység-potenciálok morfológiáját (alak, amplitúdó, időtartam) elemezzük. A vázizomtól eltérően a gégében egy idegrost csak kisebb izomcsoportokat innervál. Ebből adódóan a mozgatóegységpotenciálok rövidebbek és kisebb amplitúdójúak a vázizmokhoz képest. Az amplitúdó az ideg által beidegzett izomrostok számát és erősségét mutatja meg, az elektromos jel hossza pedig az ingerület sebességétől függ, amelyet az idegrost „szigetelése” befolyásol. Az izomkontrakció erejét a múködő mozgatóegységek száma és ezek kisülési frekvenciája határozza meg. Az izomerő fokozásakor egyre több mozgatóegység egyre magasabb kisülési frekvenciával aktiválódik. Ezt a folyamatot recruitmentnek nevezzük. Ennek megfelelően az EMG során regisztrált jelsűrúség a növekvő izomerővel párhuzamosan aktiválódó motoros egységek számával arányos. Az ideg- és izomsérülések a normális mozgatóegységpotenciálok számának és a recruitmentnek a csökkenéséhez vezethetnek az izmok akaratlagos aktivitásakor [6].

A tüelektróda izomba történő beszúrásakor insertiós aktivitás jelentkezhet. Jellemzően ez egy sorozat erős elektromos kisülést jelent, melyek hossza nem több néhány száz milliszekundumnál (3. ábra). A jelenség annak köszönhető, hogy az elektróda maga is raktároz valamennyi elektromos töltést, így az izom membránjára helyezve relatív töltéskülönbséget hoz létre. Ha az izmot körülvevő elektromos töltés nem stabil (korai idegsérülés vagy izomsérülés esetén), az insertiós aktivitás ideje meg-

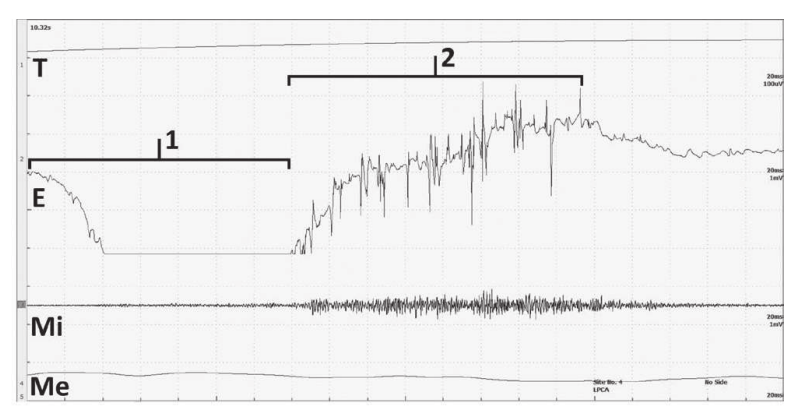

3. ábra $\quad$ Insertiós aktivitás nyugodt belégzés közben a bal oldali musculus cricoarytenoideus posteriorban pajzsmirigymútét következtében kialakult kétoldali hangszalagbénulás után 9 hónappal. A gyürüporc penetrálásakor mért elektromos jelek (1) kívül esnek az elóre beállított mérési tartományon. Az izom elérésekor normális hosszúságú insertiós aktivitás detektálható (2). Az endoscopos kép a bal oldali gégefél ab- és adductiós mozgásainak csaknem teljes regenerálódását mutatta

$\mathrm{E}=\mathrm{EMG} ; \mathrm{Me}=$ mellkasi öv $; \mathrm{Mi}=$ mikrofon $; \mathrm{T}=$ termométer 
nyúlik. Ideg- és izomsérülések esetén az idő múlásával a normálizomszövetet zsír vagy hegszövet helyettesíti, ami az insertiós aktivitás csökkenéséhez vezet [6].

A vázizmokkal szemben, ahol nyugalomban szinte teljes elektromos csendet tudunk regisztrálni, egészséges, éber betegnél a gége teljes relaxálása csaknem lehetetlen. A nyugalmi állapotot leginkább nyugodt belégzéskor vizsgálhatjuk LEMG során. A fiziológiás háttéraktivitás így is nehézzé teszi az insertiós aktivitás megítélését. Szintén nehezebb a patológiás spontán aktivitás (SPA) detektálása. Másrészrôl azonban az idegsérülések csökkentik a gégeizmok háttéraktivitását. Ez a jelenség néha megkönnyítheti a vizsgálatot.

A spontán patológiás aktivitás (SPA) jeleit nyugalomban lévő izomban, mozdulatlan tüelektróda mellett kell keresnünk. Fiziológiás állapotok mellett spontán patológiás aktivitással nem találkozunk. A SPA magában foglalja a fibrillációs potenciálokat (4. ábra), a megnövekedett

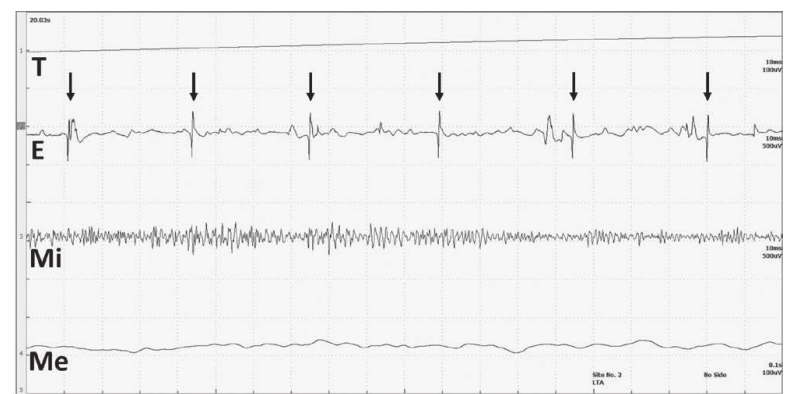

4. ábra

Fibrillációs potenciálok a bal oldali musculus thyroarytenoideusban nyugodt belégzés közben pajzsmirigymútét következtében kialakult kétoldali hangszalagbénulás után 9 hónappal. Az endoscopos kép a bal oldali gégefél ab- és adductiós mozgásainak csaknem teljes regenerálódását mutatta

nyíl $=$ fibrillációs potenciál $; \mathrm{E}=\mathrm{EMG} ; \mathrm{Me}=$ mellkasi öv; $\mathrm{Mi}=$ mikrofon; $\mathrm{T}=$ termométer

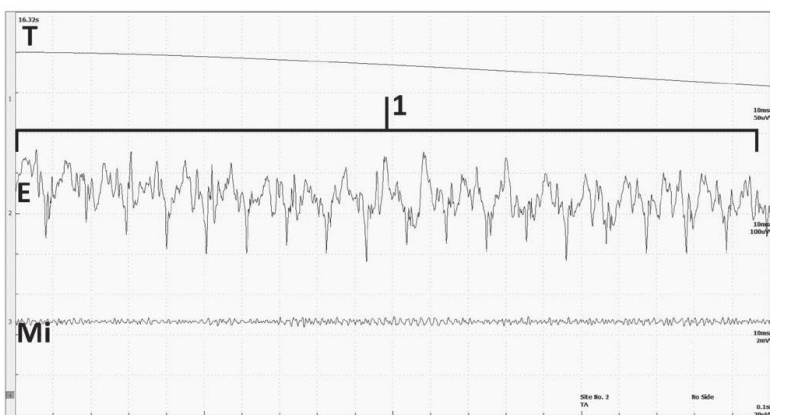

5. ábra

Komplex ismétlődő kisülések nyugodt belégzés közben a ba oldali musculus thyroarytenoideusban pajzsmirigymútét következtében kialakult bal oldali hangszalagbénulás után 30 hónappal. A komplex ismétlődő kisüléseket krónikus denerváció esetén regisztrálhattuk. Több izomrost egymás utáni, mindig azonos sorrendben történő kisüléséről van szó, ahol egy fibrilláló izomrost pacemakerként szerepel. Az endoscopos kép a bal oldali gégefél teljes immobilitását mutatta

$\mathrm{l}=$ komplex ismétlődő kisülések; $\mathrm{E}=\mathrm{EMG} ; \mathrm{Mi}=$ mikrofon; $\mathrm{T}$ = termométer insertiós aktivitást, a myotonicus kisüléseket, a komplex ismétlődő kisüléseket (5. ábra), a fasciculatiókat és a pozitív éles hullámokat. A leggyakrabban fibrillációs potenciálokat regisztrálhatunk. Ezek alacsony amplitúdójú, rövid ideg tartó jelek, amelyek az axonok degenerációjához köthetők, és jellemzően az idegsérülést követő 1014. napon jelennek meg. A denerváció ilyen foka csak súlyos idegsérüléskor látható, ami a regeneráció szempontjából rossz prognózist jelent. Hangsúlyozandó, hogy denerváció alatt nincs neuralis input az izomban, így abnormális hullámformák sincsenek. Ezek csak a regeneráció alatt jelennek meg [6].

$\mathrm{Az}$ elektrofiziológiai mérések eredményeit megfeleltethetjük a perifériás idegsérülések Seddon-féle klasszifikációjának [16]. Amennyiben single-fiber aktivitást (6. ábra) vagy megritkult recruitmentmintázatot (7. ábra) észlelünk akaratlagos aktivitás alatt, és emellett nem regisztrálunk spontán patológiás aktivitást, neurapraxiáról
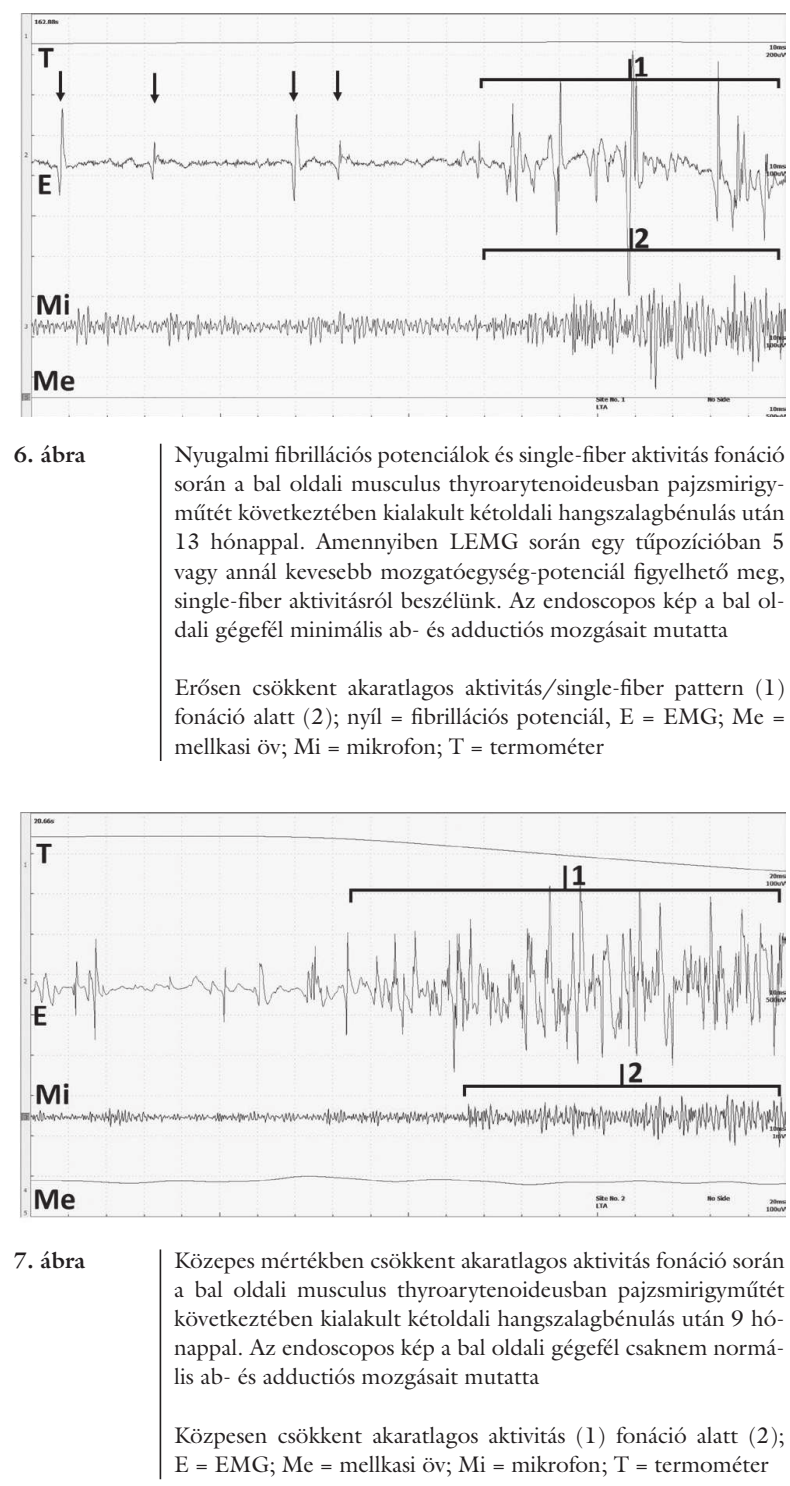


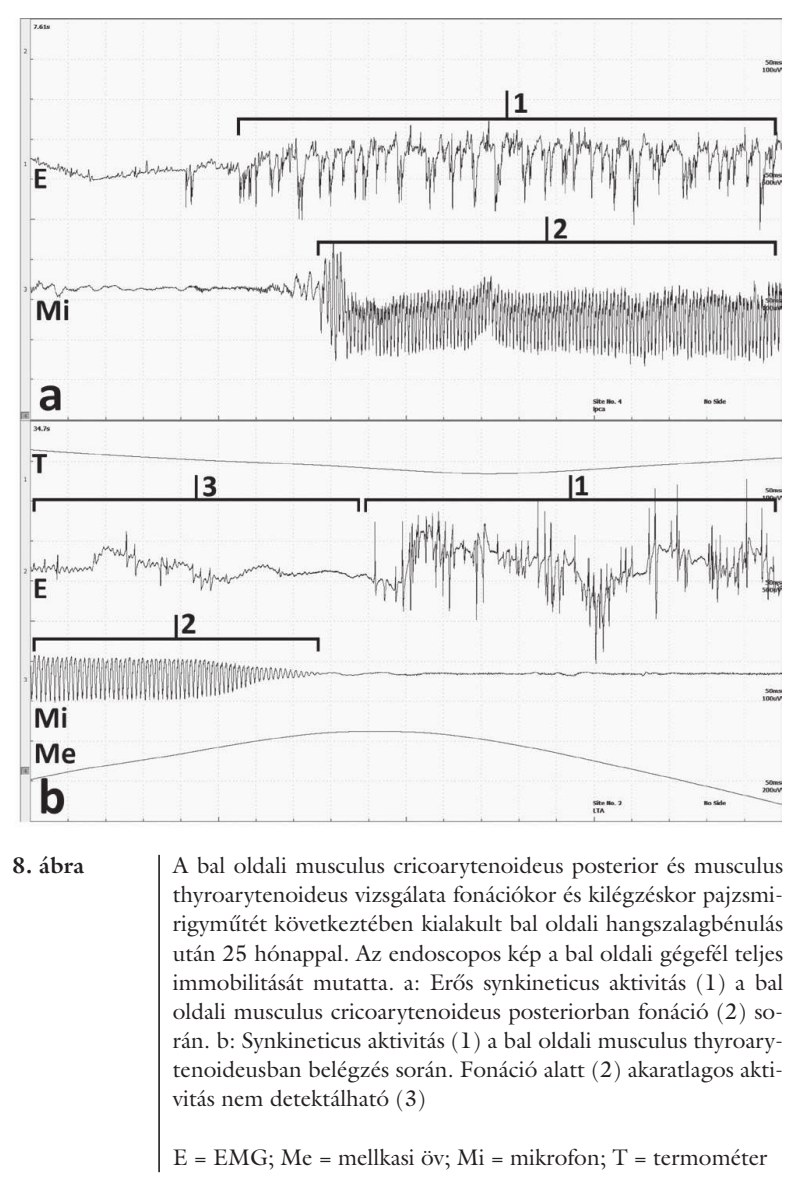

beszélünk, és $8-12$ hét alatt a beidegzés regenerációjára számíthatunk. A regeneráció folyamán a polifázisos potenciálok száma és a mozgatóegység-potenciálok amplitúdója nő, a fibrillációs potenciálok száma csökken. Axonotmesist valószínúsít, ha idegi degenerációra utaló spontán patológiás aktivitást észlelünk. Ebben az esetben jóval kisebb az esély a beidegzés regenerációjára. Ha mégis reinnerváció következik be, az jellemzően synkinesissel (a gégeizmok együttes ab- és adductiós aktivitásával) jár [17-21] (8. ábra). Neurotmesis esetén az ideg teljes keresztmetszetében károsodást szenved. Ilyen esetben reinnerváció ritkán, csak az idegvégek direkt kontaktusa esetén jöhet létre.

\section{Megbeszélés}

A laryngealis electromyographiát (LEMG) 1944-ben Weddel és mtsai vezették be [22]. A következő évtizedekben (Faaborg-Andersen, 1956; Buchthal, 1959; Knutsson, 1969; Gay, 1972; Haglund, 1973) a módszert ugyan jelentős mértékben továbbfejlesztették [23-27], de csak az 1980-as, '90-es években vált széles körben elterjedt diagnosztikai eszközzé. Magyarországon is voltak próbálkozások a LEMG bevezetésére, azonban a nem megfelelő technikai feltételek, a vizsgálati protokoll és a konszenzus hiánya megakadályozta a módszer széles körben történő elterjedését [28].

Amennyiben a hangszalag(ok) ab- vagy adductiós mozgásai csökkentek vagy teljesen hiányoznak, a nemzetközi irodalomban szívesebben használják a „hangszalag-immobilitás” terminust, mint a korábban használt „hangszalagbénulás” kifejezést. Habár a hangszalag-immobilitás hátterében a leggyakrabban valóban hangszalagbénulás áll, hasonló állapotot tud több, a beidegzési problémáktól független kórkép is előidézni. Az utóbbi csoportot összességében mechanikus fixációs problémáknak nevezzük. Ez utóbbi esetén, ahol a gége beidegzése intakt, általában hegesedés vagy a cricoarytenoidealis ízület ankylosisa magyarázza a csökkent mozgást. Normális hullámformák és interferenciamintázat hangszalag-immobilitás esetén mechanikus fixációt igazol (9. ábra) [8]. Ezzel szemben a valódi bénulásos kórképeknél jellegzetes eltéréseket regisztrálunk a LEMG során. A vizsgálatkor észlelt spontán patológiás aktivitás, a polifázisos mozgatóegység-potenciálok, a neuropathiás interferenciamintázatok idegsérülésre jellemzőek, és paresist, illetve paralysist valószínúsítenek.

A LEMG eredményéből következtethetünk a prognózisra is, mivel a patológiás spontán aktivitás hiánya és a mozgatóegység-potenciál normális/közel normális morfológiája általában jó prognózisra, valószínúsíthető reinnervációs folyamatra utal. Hasonlóan biztató jelként értékelhető a hangerő erősödésekor észlelt „recruitment spike”-ok szinkrón sûrüsödése. Gyenge prognózist jelent ezzel szemben a spontán patológiás aktivitás jelenléte, tehát akaratlagos gégemozgástól függetlenül is észlelhető, általában alacsony amplitúdójú akciós potenciálok detektálása és a csökkent vagy teljesen hiányzó recruitment [4].

A gége reinnervációja komplex és bizonytalan kimenetelú folyamat. Az alapvetô probléma az, hogy a sérült idegszakaszon a regeneráció során az adduktor és abduktor rostok keverednek, és a kevert beidegzés miatt jelentősen csökken az akaratlagos mozgások hatékonysága.

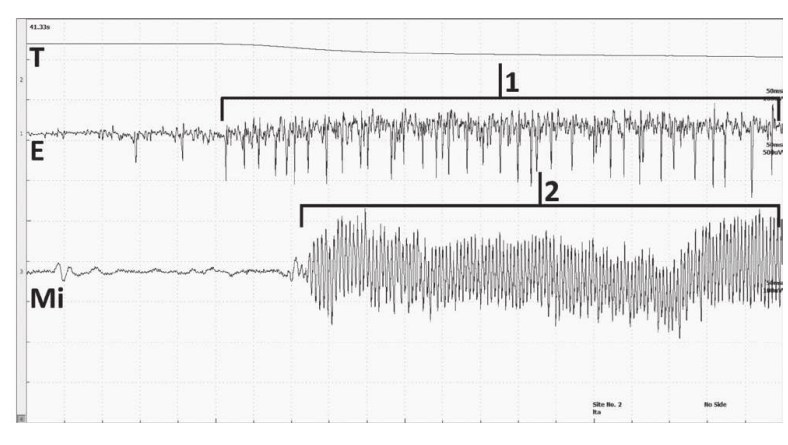

9. ábra

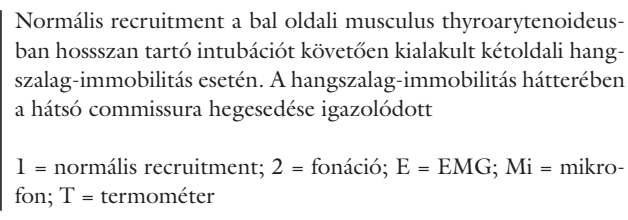


Ez a kontraproduktív reinnerváció tehető felelőssé az enyhe fokú maradványtünetek (pl. kisfokú rekedtség, nem teljesen jól nyíló gégefél miatti, csak terheléskor jelentkező dyspnoe) mellett a gyakran súlyos, a teljes gégebénulás képét utánzó súlyos funkciózavarokért is. Az ilyen aberráns reinnervációt más néven synkineticus regenerációnak nevezzük. Mivel ezekben az esetekben többé-kevésbé mind a záró-, mind a nyitóizmokban, mind belégzés és fonáció alatt akaratlagos aktivitás mutatható ki, a LEMG önmagában képtelen elkülöníteni a funkcionális és a kontraproduktív reinnervációt [4]. Ez a magyarázata annak, hogy a hangszalagbénulás endoscopos képekkel látható végkifejlete nem mindig felel meg a LEMG során feltételezett prognózisnak. A metaanalízisek szerint tehát a LEMG nagy biztonsággal képes meghatározni a reinnerváció kedvezőtlen kimenetelét, azonban a potenciálisan kedvező LEMG-jelek ellenére a klinikailag észlelt reinnerváció nem egyértelmû a lehetséges synkineticus folyamatok kialakulása miatt $[4,8$, 29-32].

A fentiek alapján a LEMG előnyei kézenfekvőek a kétoldali hangszalagbénulás optimális terápiájának meghatározásában. Amennyiben súlyos dyspnoét okozó hangszalag-immobilitás esetén a fiziológiás LEMG-lelet alátámasztja a mechanikus fixáltság fennállását, a lehetőleg funkciókímélő hangréstágító műtét elvégzése mihamarabb indokolt [33-36]. Amennyiben a vizsgálat idegi eredetű mozgászavart igazol, a klasszikus elveknek megfelelően eltérő stratégiát kell választani. Tovább árnyalja a kérdést az a tény, hogy a modern mútéti eljárások (pl. az intraoperatív idegmonitorozás) bevezetése érdemben nem csökkentette a nervus laryngeus inferior területén végzett mútétek (leggyakrabban pajzsmirigyműtét) következtében kialakuló nervus recurrens sérülések gyakoriságát. Arányaiban azonban megnőtt a reverzibilisnek tartható bénulások száma [37-39]. Emiatt sok szerzô még napjainkban is minimum 6 hónapos várakozási időt javasol a definitív hangréstágító mútét előtt (akár az életminőséget jelentősen rontó ideiglenes tracheotomiával) a spontán reinnerváció lehetősége miatt [40]. A LEMG segítségével azonban már a bénulás korai szakaszában, néhány héten belül lehetôségünk nyílik azon betegek elkülönítésére, akiknél az idegsérülés súlyossága miatt nem érdemes várni a hangréstágító mútét elvégzésével. Ezekben az esetekben a munkacsoport tapasztalatától függően külső (pl. Réthi- [I-II.], King-Schobel-mütét) vagy belső feltárásból végezhető beavatkozások széles tárháza (pl. laser arytenoidectomia, posterior chordotomia) áll rendelkezésre. A jó prognózisú vagy bizonytalan esetekben a bénulás ezen szakaszában a tracheotomia helyett jó alternatív megoldás lehet olyan mütéti technikákat előnyben részesíteni, amelyek kevésbé károsítják a gégét, tehát potenciálisan reverzibilisek. Ilyen megoldás lehet a kannaporc fonállal történő endoscopos rögzítése, a klinikánkon kidolgozott endoscopos arytenoid abductiós lateropexia [41-45]. A kétoldali bénulás esetén a LEMG döntő szerepet játszhat a hangréstágító műtét oldalának meghatározásában is, hiszen ezeket a beavatkozásokat ott érdemes elvégezni, ahol a regeneráció kevésbé valószínú.

Napjainkban a gégebénulások sebészi kezelésében jelentôs paradigmaváltás tapasztalható. A fenti, többségében statikus megoldásokkal szemben egyre inkább előtérbe kerülnek a dinamikus hangréstágító módszerek modern változatai. Ilyen például a reinnervációs procedúrák klinikai gyakorlatba történő rutinszerű bevezetése, melyek közül az egyik legelterjedtebb a gégeizmoknak a nervus phrenicusszal vagy a nervus hypoglossusszal történő szelektív reinnervációja. Ezek az eljárások azonban csak akkor végezhetők el sikeresen, ha a bénulás hátterében nem paralysis, hanem az idegregeneráció során a nyitó és záró beidegzés keveredéseként létrejött synkineticus aktivitás alakult ki, mivel ezekben az esetekben a folyamatos ingerlés hatására az izomatrófia elhanyagolható, és a sérüléstől általában distalisan elhelyezkedő végágak anasztomózisa képes a hatékony izommozgás kivitelezésére $[42,46]$. A rendkívül bonyolult reinnervációs mütétek kiváltását jelentő, várhatóan hamarosan az ilyen típusú bénulások standard megoldásává váló „laryngeals pacing" alkalmazása során az izmok funkciószinkrón mozgatását egy implantátumon keresztül az izomba helyezett elektródákkal érjük el. A mozgás azonban ebben az esetben is csak akkor valósítható meg, ha az elektródát izmokba belépő synkineticus regenerációt mutató idegek közelébe tudjuk behelyezni, mivel izmok direkt ingerlése nem energiahatékony [47, 48]. Ezekben az esetekben is nyilvánvaló a LEMG szerepe a megfelelő betegcsoport kiválasztásában.

\section{Következtetés}

Összefoglalásként elmondható, hogy a LEMG a mai napig technikailag bonyolult, nagy szakmai tapasztalatot igénylő eljárás [7]. Ám az új terápiás módszerek, a gégebénulás és a regeneráció patofiziológiájának jobb megismerése, illetve az ebből fakadó modern mútéti koncepciók megjelenése és ezek közül az optimális beavatkozás kiválasztása mindenképpen szükségessé teszi a LEMG rutinszerü alkalmazását a gégészeti centrumokban.

Anyagi támogatás: A közlemény megírása, illetve a kapcsolódó kutatómunka anyagi támogatásban nem részesült.

Szerzői munkamegosztás: B. Á.: A kézirat megszövegezése, irodalmi áttekintés, az electromyographiás mérések elvégzése. Sz. B.: Lektorálás, az electromyographiás mérések elvégzése. K. J. G., G. F. V., A. M., C. P.: Szakmai tanácsadás, az electromyographiás mérések koordinálása. R. L.: Lektorálás, szakmai tanácsadás, az electromyographiás mérések koordinálása. A cikk végleges változatát valamennyi szerző elolvasta és jóváhagyta.

Érdekeltségek: A szerzőknek nincsenek érdekeltségeik. 


\section{Irodalom}

[1] Hirschberg J, Hacki T, Mészáros K. Phoniatrics and related professions. [Foniátria és társtudományok.] ELTE Eötvös Kiadó, Budapest, 2013. [Hungarian]

[2] Sataloff RT, Mandel S, Mann EA, et al. Practice parameter: laryngeal electromyography (an evidence-based review). J Voice 2004; 18: 261-274.

[3] Blitzer A, Crumley RL, Dailey SH, et al. Recommendations of the Neurolaryngology Study Group on laryngeal electromyography. Otolaryngol Head Neck Surg. 2009; 140: 782-793.

[4] Rickert SM, Childs LF, Carey BT, et al. Laryngeal electromyography for prognosis of vocal fold palsy: a meta-analysis. Laryngoscope 2012; 122: 158-161.

[5] Kotby MN, Fadly E, Madkour O, et al. Electromyography and neurography in neurolaryngology. J Voice 1992; 6: 159-187.

[6] Volk GF, Hagen R, Pototschnig C, et al. Laryngeal electromyography: a proposal for guidelines of the European Laryngological Society. Eur Arch Otorhinolaryngol. 2012; 269: 2227-2245.

[7] Volk GF, Pototschnig C, Mueller A, et al. Teaching laryngeal electromyography. Eur Arch Otorhinolaryngol. 2015; 272: 1713-1718.

[8] Meyer TK, Hillel AD. Is laryngeal electromyography useful in the diagnosis and management of vocal fold paresis/paralysis? Laryngoscope 2011; 121: 234-235.

[9] Yang Q, Xu W, Li Y, et al. Value of laryngeal electromyography in spasmodic dysphonia diagnosis and therapy. Ann Otol Rhinol Laryngol. 2015; 124: 579-583.

[10] Sulica L, Blitzer A: Botulinum toxin treatment of spasmodic dysphonia. Op Tech Otolaryngol Head Neck Surg. 2004; 15: 7680.

[11] Kaszás Zs, Lichtenberger Gy, Mészáros K. Treatment of adduc tor spasmodic dysphonia by EMG-controlled Botolinum "A" injection. [ $\mathrm{Az}$ adductor típusú spasmodicus dysphonia kezelése EMG-kontroll melletti Botulinum „A” injektálással.] Fül-OrrGégegyógy. 2001; 47: 24-27. [Hungarian]

[12] Wang CC, Chang MH, Jiang RS, et al. Laryngeal electromyography-guided hyaluronic acid vocal fold injection for unilateral vocal fold paralysis: a prospective long-term follow-up outcome report. JAMA Otolaryngol Head Neck Surg. 2015; 141: 264 271.

[13] Komár J, Kiss G. Clinical electromyography. [Klinikai elektromiográfia.] Golden Book Kiadó, Budapest, 2000. [Hungarian]

[14] Maturo SC, Hartnick CJ. Pediatric laryngeal electromyography. Adv Otorhinolaryngol. 2012; 73: 86-89.

[15] Sedghamiz H, Santonocito D. Unsupervised detection and classification of motor unit action potentials in intramuscular electromyography signals. The 5th IEEE International Conference on E-Health and Bioengineering - EHB 2015. At Iasi, Romania.

[16] Seddon HJ. Three types of nerve injury. Brain 1943; 66: 237 288

[17] Sittel C, Stennert E. Prognostic value of electromyography in acute peripheral facial nerve palsy. Otol Neurotol. 2001; 22: 100-104.

[18] Sittel C, Stennert E, Thumfart WF, et al. Prognostic value of laryngeal electromyography in vocal fold paralysis. Arch Otolaryngol Head Neck Surg. 2001; 127: 155-160.

[19] Blitzer A, Jahn AF, Keidar A. Semon's law revisited: an electromyographic analysis of laryngeal synkinesis. Ann Otol Rhinol Laryngol. 1996; 105: 764-769.

[20] Kirchner JA. Semon's law a century later. J Laryngol Otol. 1982; 96: 645-657.

[21] Clarence TS, Masatoshi H, Takestugu I, et al. Vocal cord positioning by selective denervation. Old territory revisited. Ann Otol Rhinol Laryngol. 1980; 89: 541-546.

[22] Weddell G, Feinstein B, Pattle RE. The electrical activity of voluntary muscle in man under normal and pathological conditions. MacMillan and Co., London, 1944.
[23] Faaborg-Andersen K, Buchthal F. Action potentials from internal laryngeal muscles during phonation. Nature 1956; 177: 340341 .

[24] Buchthal F. Electromyography of intrinsic laryngeal muscles. Q J Exp Physiol Cogn Med Sci. 1959; 44: 137-148.

[25] Knutsson E, Martensson A, Marrtensson B. The normal electromyogram in human vocal muscles. Acta Otolaryngol. 1969; 68: $526-536$.

[26] Gay T, Hirose H, Strome M, et al. Electromyography of the intrinsic laryngeal muscles during phonation. Ann Otol Rhino Laryngol. 1972; 81: 401-409.

[27] Haglund S. The normal electromyogram in human cricothyroid muscle. Acta Otolaryngol. 1973; 75: 448-453.

[28] Lichtenberger Gy, Kaszás Zs, Reményi Á. Importance of the EMG, Mitomycin-C and endo-extralaryngeal suture technique by the management of posterior commissura scars. [EMG, Mitomycin-C és endo-extralaryngealis varrattechnika jelentősége a commissura posterior stenosis kezelésében.] Fül-Orr-Gégegyógy. 2005; 51: 56-59. [Hungarian]

[29] Pardo-Maza A, García-Lopez I, Santiago-Pérez S, et al. Laryngeal electromyography for prognosis of vocal fold paralysis. J Voice 2017; 31: 90-93.

[30] Wang CC, Chang MH, De Virgilio A, et al. Laryngeal electromyography and prognosis of unilateral vocal fold paralysis - a long-term prospective study. Laryngoscope 2015; 125: 898903.

[31] Focquet A, Péréon Y, Ségura S, et al. Diagnostic and prognostic contribution of laryngeal electromyography in unilateral vocalfold immobility in adults. Eur Ann Otorhinolaryngol Head Neck Dis. 2016; 134: 13-18.

[32] Gavazzoni FB, Scola RH, Lorenzoni PJ, et al. The clinical value of laryngeal electromyography in laryngeal immobility. J Clin Neurosci. 2011; 18: 524-527.

[33] Hoasjoe DK, Franklin SW, Aarstad RF, et al. Posterior glottic stenosis mechanism and surgical management. Laryngoscope 1997; 107: 675-679.

[34] Gardner GM. Posterior glottic stenosis and bilateral vocal fold immobility: diagnosis and treatment. Otolaryngol Clin North Am. 2000; 33: 855-878.

[35] Wolf M, Primov-Fever A, Talmi YP, et al. Posterior glottic stenosis in adults. Isr Med Assoc J. 2007; 9: 597-599.

[36] Stephenson KA, Wyatt ME. Glottic stenosis. Semin Pediatr Surg. 2016; 25: 132-137.

[37] Pisanu A, Porceddu G, Podda M, et al. Systematic review with meta-analysis of studies comparing intraoperative neuromonitoring of recurrent laryngeal nerves versus visualization alone during thyroidectomy. J Surg Res. 2014; 188: 152-161.

[38] Lombardi CP, Carnassale G, Damiani G, et al. "The final countdown": Is intraoperative, intermittent neuromonitoring really useful in preventing permanent nerve palsy? Evidence from a meta-analysis. Surgery 2016; 160: 1693-1706.

[39] Rulli F, Ambrogi V, Dionigi G, et al. Meta-analysis of recurrent laryngeal nerve injury in thyroid surgery with or without intraoperative nerve monitoring. Acta Otorhinolaryngol Ital. 2014; 34: 223-229.

[40] Sapundzhiev N, Lichtenberger G, Eckel HE, et al. Surgery of adult bilateral vocal fold paralysis in adduction: history and trends. Eur Arch Otorhinolaryngol. 2008; 265: 1501-1514.

[41] Szakács L, Sztanó B, Matievics V, et al. A comparison between transoral glottis-widening techniques for bilateral vocal fold immobility. Laryngoscope 2015; 125: 2522-2529.

[42] Sandhu GS, Nouraei SAR, Rovó L, et al. Bilateral impaired vocal cord mobility. In: Sandhu GS, Nouraei SAR. (eds.) Laryngeal and tracheobronchial stenosis. Plural Publishing, San Diego, CA, 2015; pp. 195-227.

[43] Rovó L, Jóri J, Brzózka M, et al. Airway complication after thyroid surgery: minimally invasive management of bilateral recurrent nerve injury. Laryngoscope 2000; 110: 140-144. 
[44] Rovó L, Madani S, Sztanó B, et al. A new thread guide instrument for endoscopic arytenoid lateropexy. Laryngoscope 2010; 120: 2002-2007.

[45] Matievics V, Bach A, Sztano B, et al. Functional outcomes of endoscopic arytenoid abduction lateropexy for unilateral vocal cord paralysis with dyspnea. Eur Arch Otorhinolaryngol. 2017; 274: 3703-3710.

[46] Marina MB, Marie JP, Birchall MA. Laryngeal reinnervation for bilateral vocal fold paralysis. Curr Opin Otolaryngol Head Neck Surg. 2011; 19: 434-438.
[47] Mueller AH. Laryngeal pacing for bilateral vocal fold immobility. Curr Opin Otolaryngol Head Neck Surg. 2011; 19: 439-443.

[48] Mueller AH, Hagen R, Foerster G, et al. Laryngeal pacing via an implantable stimulator for the rehabilitation of subjects suffering from bilateral vocal fold paralysis: A prospective first-in-human study. Laryngoscope 2016; 126: 1810-1816.

(Bach Ádám dr., Szeged, Tisza Lajos krt. 111., 6725 e-mail: bach.adam@med.u-szeged.hu)

\section{MEGHÍVÓ}

Ünnepi Tudományos Ülés és szoborcsoport avatás Semmelweis lgnác születésének 200. évfordulója tiszteletére - Tisztelgés Semmelweis Ignác előtt 200. születésnapja alkalmából a Semmelweis Egyetem szülész „honoris causa” díszdoktorainak részvételével

Idôpont: 2018. június 30. (szombat), 10:00-15:00

Helyszín: Semmelweis Egyetem Nagyvárad téri Elméleti Tömb, Díszterem Szervező elnökök: Prof. Dr. Papp Zoltán és Prof. Dr. Rosivall László

Rendezők: Semmelweis Egyetem, Orvosi Hetilap, Semmelweis Kiadó, Professional Publishers, Akadémiai Kiadó Zrt., lan Donald Inter-University School (a Magyar Tagozat 15. rendezvénye), Medicina Könyvkiadó Zrt. és a magyar szülészorvos társadalom (Magyar Nóorvosok Társasága)

Házigazda: A Semmelweis Egyetem és a Maternity Szülészeti és Nőgyógyászati Magánklinika, Budapest

\section{PROGRAM}

A transformative icon for modern perinatology

Üléselnökök: Prof. Dr. Szél Ágoston, a Semmelweis Egyetem rektora, Prof. Dr. Merkely Béla, a Semmelweis Egyetem rektorjelöltje és Prof. Dr. Bódis József, a Pécsi Tudományegyetem rektora, a Magyar Nőorvos Társaság elnöke

10:00 - 13:20

Prof. Dr. Rosivall László (Budapest): Semmelweis, aki felfedezte a kórt, de nem győzte meg a kort

Prof. Dr. Dr. h.c. Frank A. Chervenak (New York):

Ethical dimensions of puerperal sepsis 170 years ago and today

Prof. Dr. Gazda István (Budapest): Semmelweis Ignác az orvostörténész szemszögéből

Prof. Dr. Dr. h.c. Roberto Romero (Detroit):

New challenges of maternal and fetal infections in the $21^{\text {st }}$ century

Prof. Dr. Kiss László (Csilizradvány): Semmelweis Ignác és az Orvosi Hetilap

Prof. Dr. Dr. h.c. Asim Kurjak (Zagreb):

The role of ultrasound in prevention and management of perinatal sepsis

Prof. Dr. Papp Zoltán (Budapest): Semmelweis Ignác késői tanszéki utódjának megemlékezése

Prof. Dr. Didier Pittet (Geneva):

Following Semmelweis

13:20-13:45

Séta a Semmelweis Egyetem Külsô Klinikai Tömbjéhez

(az egyetem II. Sz. Szülészeti és Nőgyógyászati Klinikájához)

13:45-14:00

Semmelweis emlékére Madarassy István művész által készített

„Áldott állapotban - Vizitáció Semmelweis emlékére" címú szoborcsoport leleplezése

14:00-15:00

Fogadás a Külső Klinikai Tömbben

Az Orvosi Hetilap (Semmelweis születésnapi emlékszám, 159. évfolyam 26. szám, 2018. július 1.) közölni fogja a négy magyar nyelvú, a Nőgyógyászati és Szülészeti Továbbképző Szemle (20. évfolyam 3 . füzet, 2018. június) pedig a három "honoris causa” díszdoktor angol nyelvũ előadását. (Mindkét lap főszerkesztője Prof. Dr. Papp Zoltán.) A résztvevők mindkét füzetet ajándékként kapják.

Egyidejűleg a helyszínen kedvezményesen megvásárolható a Rosivall László szerkesztésében megjelenő Semmelweis Emlékkötet magyar és angol nyelvű változata (Semmelweis Kiadó, Budapest, 2018) és a Papp Zoltán által szerkesztett Szülészet-Nőgyógyászat Trilógia kötetei („A várandósgondozás kézikönyve”, 2016, „A perinatológia kézikönyve. Második kiadás”, 2018 és „A nőgyógyászat kézikönyve”, 2016, Medicina Könyvkiadó Zrt., Budapest), továbbá a Semmelweis Kiadó legújabb könyve, a Papp Zoltán által írt "A szülészet-nőgyógyászat tankönyve. Ötödik kiadás”, 2017 kötet.

Részvételi dij nincs, elốzetes regisztráció szükséges a www.semmelweis. hu honlap eseménynaptárában az adott napi programnál 